Supporting Information

\title{
Near-Infrared Photothermal/Photodynamic-in-One Agents Integrated with a Guanidinium-Based Covalent Organic Framework for Intelligent Targeted Imaging-Guided Precision Chemo/PTT/PDT Sterilization
}

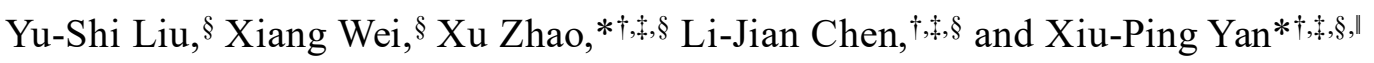

$\dagger$ State Key Laboratory of Food Science and Technology, Jiangnan University, Wuxi 214122, China.

* International Joint Laboratory on Food Safety, Jiangnan University, Wuxi 214122, China.

$\S$ Institute of Analytical Food Safety, School of Food Science and Technology, Jiangnan University, Wuxi 214122, China.

" Key Laboratory of Synthetic and Biological Colloids, Ministry of Education, School of Chemical and Material Engineering, Jiangnan University, Wuxi, 214122, China.

* E-mail: xpyan@jiangnan.edu.cn

*E-mail: zhaoxu2017@jiangnan.edu.cn 


\section{Supplementary Methods}

Chemicals and Materials. 2',7'-dichlorodihydrofluorescein diacetate (DCFH-DA) and $N$-(2-hydroxyethyl) piperazine were purchased from Aladdin Reagent Co. Ltd (Shanghai, China). 1,4-benzenedicarboxaldehyde (Dha) was bought from Yanshen Technology Co. Ltd (Jilin, China). Guanidine hydrochloride, tetrahydrofuran (THF), hydrazine hydrate and ethanol were provided from Sinopharm Chemical Reagent Co. Ltd (Shanghai, China). 1,3diphenylisobenzofuran (DPBF) was purchased from Macklin Co. Ltd (Shanghai, China). 3-(4,5-Dimethyl-thiazol-2-yl)-2,5-diphenyltetrazolium bromide (MTT), 4',6-diamidino-2phenylindole (DAPI), Calcein acetoxymethyl ester and propidium iodide (Calcein-AM/PI) live and dead bacteria detection kit were supplied from Sigma-Aldrich Co. LLC (Shanghai, China). Culture medium and consumables for cell culture were supplied by Dingguo Biotechnology Co. (Beijing, China). Other reagents were of at least of analytical grade and used without further purification.

Instrumentation and Characterization. ${ }^{1} \mathrm{H}$ and ${ }^{13} \mathrm{C}$ nuclear magnetic resonance spectra $\left({ }^{1} \mathrm{H}\right.$ NMR and ${ }^{13} \mathrm{C}$ NMR) were acquired on a Bruker AVANCE III HD $400 \mathrm{MHz}$ spectrometer (Bruker, Switzerland). Absorption and fluorescence spectra were recorded on a UV 3600 PLUS UV-vis-NIR spectrophotometer (Shimadzu, Japan) and an F-7000 fluorospectro photometer (Hitachi, Japan), respectively. Mass spectrometry was acquired on the QTRAP 4500 LC-MS/MS (Thermo, America). Fourier transform infrared (FT-IR) spectra were recorded on a Nicolet IS10 spectrometer (Thermo Scientific, USA). Transmission electron microscopy images (TEM) were obtained at $200 \mathrm{kV}$ with a JEM2100 TEM (JEOL, Japan). Zeta potential were measured on a ZEN3700 Nano laser particle 
size analyzer (Marvin, England). Bacterial imaging was acquired on a FV3000 confocal laser scanning microscope (Olympus, Japan). In vivo fluorescence imaging of mice was carried out on an IVIS Lumina III imaging system (PerkinElmer, USA). Neutrophilic granulocyte percentage was measured by a BC-5000Vet automatic hemocyte analyzer (ThermoFisher, USA).

Synthesis of Hydroxyethyl Piperazine Functionalized Cyanine. Compound 1 was prepared according to the previous reported method. ${ }^{1} \mathrm{MS}$ (ESI+), m/z: [M] ${ }^{+}$calcd 627.30, found 627.30 .

Compound 1 (0.32 g, $0.51 \mathrm{mmol})$ and $N$-(2-hydroxyethyl) piperazine $(1 \mathrm{~mL})$ were dissolved in ethanol $(20 \mathrm{~mL})$ with stirring for $2 \mathrm{~h}$ at $50^{\circ} \mathrm{C}$ in the dark, then the resulting mixture was extracted with $\mathrm{CH}_{2} \mathrm{Cl}_{2}$ and concentrated with vacuum rotatory evaporator. Finally, the crude product was purified via silica gel column chromatography with gradient elution (EA to $\mathrm{CH}_{2} \mathrm{Cl}_{2} / \mathrm{CH}_{3} \mathrm{OH}$ of 20:1). Yield: $0.28 \mathrm{~g}, 76.1 \%$. MS (ESI+), m/z: [M] ${ }^{+}$calcd 721.43 , found 721.43 .

The compound $2(0.25 \mathrm{~g}, 0.35 \mathrm{mmol})$ was dissolved in ethanol $(30 \mathrm{~mL})$, and then the resulting mixture was alkalified with $\mathrm{NaOH}$ solution $\left(1 \mathrm{~mol} \mathrm{~L}^{-1}\right)$. After stirring for $1 \mathrm{~h}$ at $40^{\circ} \mathrm{C}$ in the dark, the solvent was evaporated in vacuum. Then the residue was dissolved in high-purity water and acidified to $\mathrm{pH} 6.0$ with $\mathrm{HCl}$ solution $\left(1 \mathrm{~mol} \mathrm{~L}^{-1}\right)$. The target compound was obtained via centrifugation, purification by silica gel column chromatography with gradient elution $\left(\mathrm{CH}_{2} \mathrm{Cl}_{2} / \mathrm{CH}_{3} \mathrm{OH}\right.$ of $20: 1$ to $\left.5: 1\right)$ and freeze-drying. Yield: $0.19 \mathrm{~g}, 79.2 \%$. MS (ESI+), m/z: $[\mathrm{M}]^{+}$calcd 693.40, found 693.30.

Synthesis of Guanidinium-Based Covalent Organic Framework. Guanidine 
hydrochloride $(2.03 \mathrm{~g}, 21.25 \mathrm{mmol})$ was added to 1,4 -dioxane $(10 \mathrm{~mL})$. Then hydrazine hydrate $(10 \mathrm{~mL})$ was slowly added under stirring and the mixture was refluxed at $50^{\circ} \mathrm{C}$ for $2 \mathrm{~h}$. After cooled to room temperature, the crude product was filtered and washed with 1,4dioxane to remove excess hydrazine hydrate and finally dried to yield $\mathrm{TG}_{\mathrm{Cl}}$.

This compound was synthesized according to our previously reported method with modifications. ${ }^{2}$ Briefly, COF was synthesized via Schiff reaction between Dha (45 mg, $0.27 \mathrm{mmol})$ and $\mathrm{TGCl}(17 \mathrm{mg}, 0.12 \mathrm{mmol})$ in $6.6 \mathrm{~mL}$ of $\mathrm{THF} / \mathrm{water} / \mathrm{CH}_{3} \mathrm{COOH}(36 \%)$ $(5.4 / 0.6 / 0.6, \mathrm{v} / \mathrm{v} / \mathrm{v})$. The reactant was placed into a teflon-lined stainless steel autoclave and sonicated for $10 \mathrm{~min}$ and then kept in an oven at $120^{\circ} \mathrm{C}$ for 3 days. COF were obtained as brown colored precipitate. The precipitate was collected by centrifugation and washed with THF, water and ethanol for twice times and dried under vacuum for $24 \mathrm{~h}$ to yield COF.

Synthesis of COF@ probe. COF $(10 \mathrm{mg})$ was dispersed in water $(18 \mathrm{~mL})$ ultrasonically. The $2 \mathrm{~mL}$ of the probe solution (ethanol, $1 \times 10^{-3} \mathrm{~mol} \mathrm{~L}^{-1}$ ) was added into the COF dispersion drop by drop and keep stirring for $24 \mathrm{~h}$ at room temperature in the dark. Then COF@ probe were obtained through centrifugation and freeze-drying.

Stability of COF@probe. To evaluate the stability of COF@ probe at different pH values, the prepared COF@ probe was dispersed in PBS (pH 6.0 or $\mathrm{pH} 7.4)$, and stored at $4^{\circ} \mathrm{C}$ for $24 \mathrm{~h}$ in the dark. The absorbance of the supernatant was measured at predetermined time interva (15 min, $30 \mathrm{~min}, 1 \mathrm{~h}, 2 \mathrm{~h}, 4 \mathrm{~h}, 6 \mathrm{~h}, 8 \mathrm{~h}, 12 \mathrm{~h}, 24 \mathrm{~h}$ ).

To evaluate the photostability of COF@ probe, $0.9 \mathrm{~mL}$ of probe $\left(1 \times 10^{-5} \mathrm{~mol} \mathrm{~L}^{-1}\right.$ in PBS) and COF@ probe $\left(0.25 \mathrm{mg} \mathrm{mL}^{-1}\right.$ in PBS, $1 \times 10^{-5} \mathrm{~mol} \mathrm{~L}^{-1}$ as probe) were exposed to a $0.6 \mathrm{~W} \mathrm{~cm}^{-2}$ of $808 \mathrm{~nm}$ laser irradiation with different times $(0 \mathrm{~s}, 10 \mathrm{~s}, 20 \mathrm{~s}, 30 \mathrm{~s}, 40 \mathrm{~s}, 50 \mathrm{~s}$, 
$1 \mathrm{~min}, 1.5 \mathrm{~min}, 2 \mathrm{~min}, 3 \mathrm{~min}, 5 \mathrm{~min}$ and $10 \mathrm{~min}$, respectively) at $\mathrm{pH}$ 7.4. The UV-vis-NIR absorption spectra of each solution were recorded after irradiation.

Evaluation of Photothermal Effect. To investigate the pH-responsive photothermal property of probe, $0.9 \mathrm{~mL}$ of probe with different concentrations were placed in $1.5 \mathrm{~mL}$ Eppendorf tubes $\left(5 \times 10^{-6} \mathrm{~mol} \mathrm{~L}{ }^{-1}, 1 \times 10^{-5} \mathrm{~mol} \mathrm{~L}^{-1}, 2 \times 10^{-5} \mathrm{~mol} \mathrm{~L}^{-1}, \mathrm{pH} 6.0\right)$, respectively. Irradiation was carried out on an $808 \mathrm{~nm}$ laser with different power density $\left(0.2 \mathrm{~W} \mathrm{~cm}^{-2}\right.$, $0.4 \mathrm{~W} \mathrm{~cm}^{-2}, 0.6 \mathrm{~W} \mathrm{~cm}^{-2}, 0.8 \mathrm{~W} \mathrm{~cm}^{-2}$ ). The temperature change of each solution was recorded by a FLIR thermal camera every 30 seconds. The solution of probe $\left(2 \times 10^{-5} \mathrm{~mol} \mathrm{~L}^{-1}, \mathrm{pH} 7.4\right)$ and PBS (10 mmol L $\mathrm{L}^{-1}, \mathrm{pH}$ 7.4) irradiated under the same condition was set as control groups.

To study the acid-activated photothermal properties of COF@probe, $0.9 \mathrm{~mL}$ of COF@ probe $\left(0.5 \mathrm{mg} \mathrm{mL}^{-1}, 2 \times 10^{-5} \mathrm{~mol} \mathrm{~L}^{-1}\right.$ as probe, $\mathrm{pH}$ 6.0) solution was exposed to an 808 $\mathrm{nm}$ laser at a power of $0.6 \mathrm{~W}$ for $10 \mathrm{~min}$. In addition, the same volume solution of COF@ probe $\left(0.5 \mathrm{mg} \mathrm{mL}^{-1}, \mathrm{pH} 7.4\right)$ and COF $\left(0.5 \mathrm{mg} \mathrm{mL}^{-1}, \mathrm{pH} 6.0\right.$ or 7.4$)$ under the same irradiation were set as control. The temperature of each solution was recorded in real time by an FLIR thermal camera.

Acid-Activated Photodynamic Performance. DPBF was used as an indicator to investigate the photodynamic performance of probe and COF@ probe. Briefly, $100 \mu \mathrm{L}$ of probe or COF@ probe $\left(0.5 \mathrm{mg} \mathrm{mL}^{-1}, 2 \times 10^{-5} \mathrm{~mol} \mathrm{~L}^{-1}\right.$ as probe, $\left.\mathrm{pH} 6.0\right)$ was mixed with DPBF solution $\left(6 \times 10^{-5} \mathrm{~mol} \mathrm{~L}^{-1}\right.$ in acetonitrile, $\left.900 \mu \mathrm{L}\right)$, and the resulting solution was adjusted to pH 6.0 by $\mathrm{HCl}\left(1 \mathrm{~mol} \mathrm{~L}^{-1}\right)$ or not. Then above solutions were irradiated with $808 \mathrm{~nm}$ laser $\left(0.6 \mathrm{~W} \mathrm{~cm}^{-2}\right)$ for different times $(0 \mathrm{~s}, 10 \mathrm{~s}, 20 \mathrm{~s}, 30 \mathrm{~s}, 40 \mathrm{~s}, 50 \mathrm{~s}, 1 \mathrm{~min}, 1.5 \mathrm{~min}, 2 \mathrm{~min}, 3$ 
min, $5 \mathrm{~min}$, and $10 \mathrm{~min}$ ). Meanwhile, the absorption spectra of each solution were measured by UV-vis-NIR spectroscopy after irradiation. The blank and control groups were carried out with the following parallel groups and irradiated under the same conditions: DPBF $\left(6 \times 10^{-5} \mathrm{~mol} \mathrm{~L}^{-1}, \mathrm{pH} 6.0 / \mathrm{pH} 7.4\right), 100 \mu \mathrm{L}$ of probe $\left(2 \times 10^{-5} \mathrm{~mol} \mathrm{~L}^{-1}, \mathrm{pH} 7.4\right), \mathrm{COF}(0.5 \mathrm{mg}$ $\mathrm{mL}^{-1}, \mathrm{pH} 6.0$ or 7.4$)$ or COF@ probe $\left(0.5 \mathrm{mg} \mathrm{mL}^{-1}, \mathrm{pH} 7.4\right)$ with $900 \mu \mathrm{L}$ of DPBF $\left(6 \times 10^{-5}\right.$ mol L-1).

In Vitro Antibacterial Effect. E. coli and S. aureus were selected as model organism, and the concentration of bacteria was determined based on the flat colony counting method.

The optimal co-incubation time was detected by using confocal microscopy (CLSM). In brief, $5 \mathrm{~mL}$ of bacterial suspension was centrifuged at $4000 \mathrm{rpm}$ for $10 \mathrm{~min}$, and resuspended in probe $\left(1 \times 10^{-5} \mathrm{~mol} \mathrm{~L}^{-1}\right.$ in $\left.\mathrm{LB}, 1 \mathrm{~mL}\right)$ and $\mathrm{COF} @$ probe $\left(0.25 \mathrm{mg} \mathrm{mL}^{-1}\right.$ in $\mathrm{LB}$, $1 \mathrm{~mL})$, respectively. After different incubation times $(0.5 \mathrm{~h}, 1 \mathrm{~h}, 2 \mathrm{~h}, 4 \mathrm{~h}, 6 \mathrm{~h}, 8 \mathrm{~h}, 11 \mathrm{~h})$ at $37^{\circ} \mathrm{C}, 200 \mu \mathrm{L}$ of bacterial suspension was taken from each group and centrifuged (5000 rpm, 3 min), followed by re-suspended with PBS $(100 \mu \mathrm{L})$. Finally, $10 \mu \mathrm{L}$ of bacterial solution was dropped onto a glass slide and covered with a coverslip for CLSM characterization.

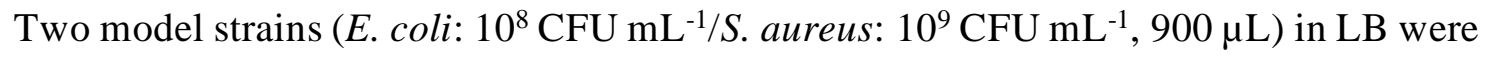
mixed with probe solution $(100 \mu \mathrm{L})$ to reach the final probe concentrations of $5 \times 10^{-6}, 1 \times 10^{-}$ ${ }^{5}, 2 \times 10^{-5} \mathrm{~mol} \mathrm{~L}^{-1}$. After $6 \mathrm{~h}$ incubation, $100 \mu \mathrm{L}$ of bacterial suspension was taken from each group and gradually diluted $10^{5}$ times (E. coli) or $10^{6}$ times (S. aureus) with PBS. Then 100 $\mu \mathrm{L}$ of diluted suspension was spread evenly over a LB agar plate and incubated in an aerophilic environment at $37^{\circ} \mathrm{C}$ for $24 \mathrm{~h}$. The dark toxicity of COF $\left(0.25 \mathrm{mg} \mathrm{mL}^{-1}, 0.5 \mathrm{mg}\right.$ 
$\mathrm{mL}^{-1}, 0.75 \mathrm{mg} \mathrm{mL}^{-1}$ ) on the two strains was investigated using the same method.

To investigate the photothermal/photodynamic antibacterial effect, E. coli or S. aureus suspension treated with COF@probe or not were divided into the following groups: Experimental group: Bacteria treated with COF@probe and exposed to an $808 \mathrm{~nm}$ laser $\left(0.6 \mathrm{~W} \mathrm{~cm}^{-2}, 10 \mathrm{~min}\right)$. A series of control groups: Bacteria in PBS; Bacteria in PBS with $808 \mathrm{~nm}$ laser irradiation; Bacteria in probe solution $\left(2 \times 10^{-5} \mathrm{~mol} \mathrm{~L}^{-1}\right)$ with or without 808 $\mathrm{nm}$ laser irradiation; Bacteria in COF solution $\left(0.5 \mathrm{mg} \mathrm{mL}^{-1}\right)$ with $808 \mathrm{~nm}$ laser irradiation or not; Bacteria in COF@ probe $\left(0.5 \mathrm{mg} \mathrm{mL}^{-1}, 2 \times 10^{-5} \mathrm{~mol} \mathrm{~L}^{-1}\right.$ as probe $)$. Then the bacterial culture method was similar to the dark toxicity test.

To further confirm the photothermal/photodynamic effect of COF@probe, the above experimental and control groups of bacteria were respectively stained by Calcein-AM/PI live-dead bacteria Staining Kit. After co-incubation for $20 \min \left(1 \mu \mathrm{mol} \mathrm{L}{ }^{-1}\right.$ of Calcein-AM and $3 \mu \mathrm{mol} \mathrm{L}{ }^{-1}$ of PI, $100 \mu \mathrm{L}$ ), the bacterial suspension was centrifuged and re-suspended in PBS. Then, CLSM imaging was carried out by dropping $10 \mu \mathrm{L}$ of the above re-suspended bacterial solution onto a glass slide.

To verify the antibacterial effect of COF@ probe was related to PTT/PDT synergistic effect, DCFH-DA was used as singlet oxygen $\left({ }^{1} \mathrm{O}_{2}\right)$ indicator. For this purpose, DCFH (20 $\mu \mathrm{L})$ solution and material/LB $(100 \mu \mathrm{L})$ were added into bacterial suspension (E. coli: $10^{8}$ CFU mL ${ }^{-1} / S$. aureus: $\left.10^{9} \mathrm{CFU} \mathrm{mL}^{-1}, 880 \mu \mathrm{L}\right)$. After incubation at $37^{\circ} \mathrm{C}$ for $6 \mathrm{~h}$, the mixture was irradiated with an $808 \mathrm{~nm}$ laser $\left(0.6 \mathrm{~W} \mathrm{~cm}^{-2}\right)$ for $10 \mathrm{~min}$ or not. Then the bacteria suspension was centrifuged (5000 rpm, $3 \mathrm{~min}$ ) and re-suspended with PBS for CLSM characterization. The experimental group and control groups were the same as that of 
photothermal/photodynamic sterilization. The temperature change of each group was recorded on a FLIR thermal camera.

Cytotoxicity Evaluation. The cytotoxicity of probe, COF and COF@probe was evaluated with a standard MTT assay. Briefly, mouse embryonic fibroblast (3T3) (100 $\mu \mathrm{L}$, $10^{5}$ cells $\mathrm{mL}^{-1}$ in DMEM) was planted in 96-well plate and incubated overnight. Then the culture medium was replaced with $100 \mu \mathrm{L}$ of fresh medium contained various concentration of COF@ probe $\left(0.125 \mathrm{mg} \mathrm{mL}^{-1}, 0.25 \mathrm{mg} \mathrm{mL}^{-1}, 0.5 \mathrm{mg} \mathrm{mL}^{-1}\right)$ for another $24 \mathrm{~h}$ incubation. The cells incubated with fresh medium only were served as blank control. Afterwards, the MTT solution $\left(0.5 \mathrm{mg} \mathrm{mL}^{-1}, 100 \mu \mathrm{L}\right)$ took place of the old medium. After incubation for 4 $\mathrm{h}$, the supernatant was discarded and $100 \mu \mathrm{L}$ of DMSO was added into each well. Finally, the absorbance was measured by a microplate reader at a wavelength of $570 \mathrm{~nm}$. In addition, the cytotoxicity of $\operatorname{COF}\left(0.125 \mathrm{mg} \mathrm{mL}^{-1}, 0.25 \mathrm{mg} \mathrm{mL}^{-1}, 0.5 \mathrm{mg} \mathrm{mL}^{-1}\right)$ and probe $\left(5 \times 10^{-6}\right.$ mol L ${ }^{-1}, 1 \times 10^{-5} \mathrm{~mol} \mathrm{~L}^{-1}, 2 \times 10^{-5} \mathrm{~mol} \mathrm{~L}^{-1}$ ) were investigated using the same method.

Fluorescence Imaging of $\boldsymbol{S}$. aureus-Infected Mice in Vivo. Female BALB/C (5-6 weeks) was purchased from Zhejiang Weitong Lihua Experimental Animal Technology Co. Ltd. All experiments were performed in strict accordance with Chinese National Standard Laboratory animal-Guideline for ethical review of animal welfare (GB/T 35892-2018) and were approved by the Institutional Animal Care and Use Committee of Jiangnan University (Wuxi, China).

For in vivo fluorescence imaging, bacterial infection-bearing mice model was first

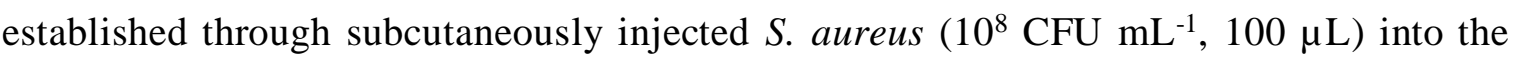
groin of mice. After $48 \mathrm{~h}$ post-infection, mice were intravenously injected with probe 
$\left(2 \times 10^{-5} \mathrm{~mol} \mathrm{~L}^{-1}, 100 \mu \mathrm{L}\right)$ or COF@ probe $\left(0.5 \mathrm{mg} \mathrm{mL}^{-1}, 100 \mu \mathrm{L}\right)$ respectively. Mice in each group were anesthetized with $1 \%$ sodium barbitone to minimize suffering during the whole operational process, and fluorescence imaging of each group mice were acquired on IVIS imaging system at different time points $(0 \mathrm{~h}, 2 \mathrm{~h}, 4 \mathrm{~h}, 6 \mathrm{~h}, 8 \mathrm{~h}, 12 \mathrm{~h}, 24 \mathrm{~h})$.

Photothermal/Photodynamic Effect in Vivo. For in vivo photothermal/photodynamic therapy effect, $S$. aureus-infected mice $(\mathrm{n}=3)$ were randomly divided into 4 groups. Experimental group: Mice intravenously injected with COF@ probe with 808 nm laser irradiation. Control groups: Mice without treatment; intravenously injected with PBS and irradiated with 808 nm laser; intravenously injected with COF@ probe only. 808 nm laser irradiation $\left(0.6 \mathrm{~W} \mathrm{~cm}^{-2}, 10 \mathrm{~min}\right)$ was applied to the abscess at $6 \mathrm{~h}$ post-injection and the temperature change of abscess were recorded by an FLIR thermal camera. Mice of each group were photographed and weighed daily, until the wounds of mice in the experimental group were completely healed.

After the whole therapeutic process, the mice were euthanized. Abscess and major organs (heart, liver, spleen, lung and kidney) were collected and fixed in 4\% paraformaldehyde solution for $H \& E$ staining to evaluate the potential side effects of the preparedCOF@probe.

In addition, to further confirm the therapeutic efficiency of COF@ probe for bacterial infection, the neutrophilic granulocyte percentage in the serum of each groups after $8 \mathrm{~d}$ treatment was measured by automatic hemocyte analyzer.

\section{Supplementary References.}

1. Zhao, X.; Yin, G. H.; Jin, D.; Yan, X. L.; Li,Yang.; Chen, L. G. A Sensitive Colorimetric and Ratiometric Chemosensor for Trivalent Metal Cations. J. Fluoresc. 2015, 25, 327-333. 
2. Da, H. J.; Yang C. X.; Yan, X. P. Cationic Covalent Organic Nanosheets for Rapid and Selective Capture of Perrhenate: An Analogue of Radioactive Pertechnetate from Aqueous Solution. Environ. Sci. Technol. 2019, 53, 5212-5220. 
Supplementary Figures

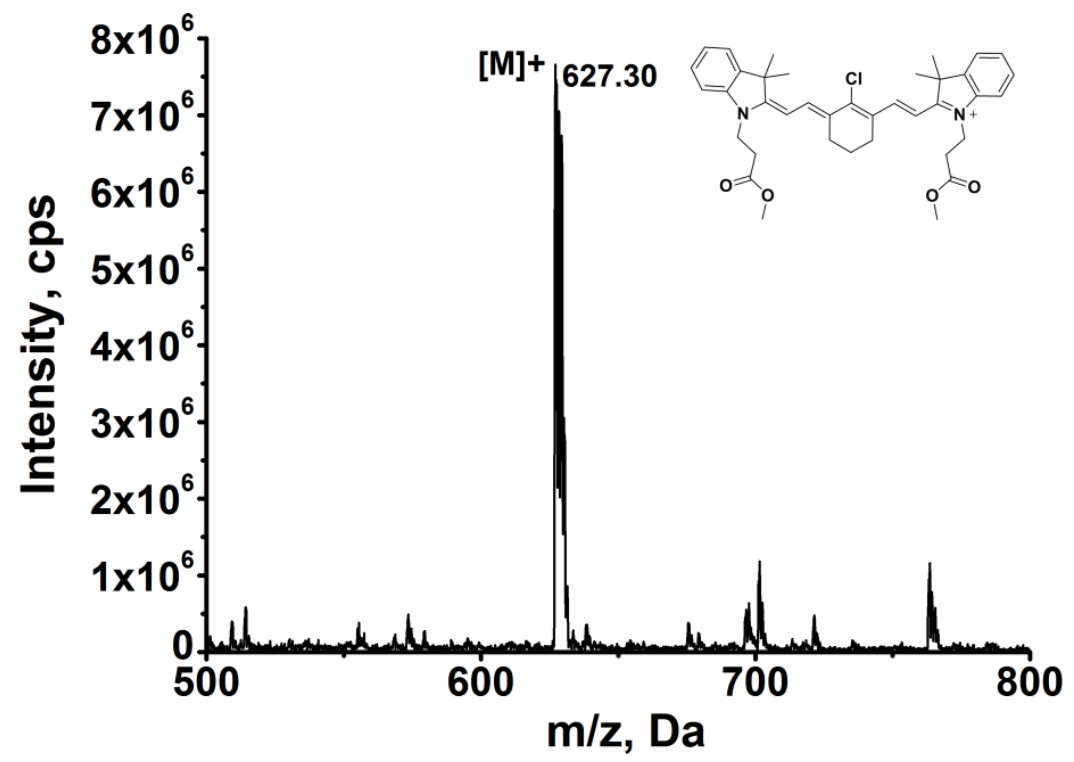

Figure S1. MS spectrum of compound 1. 


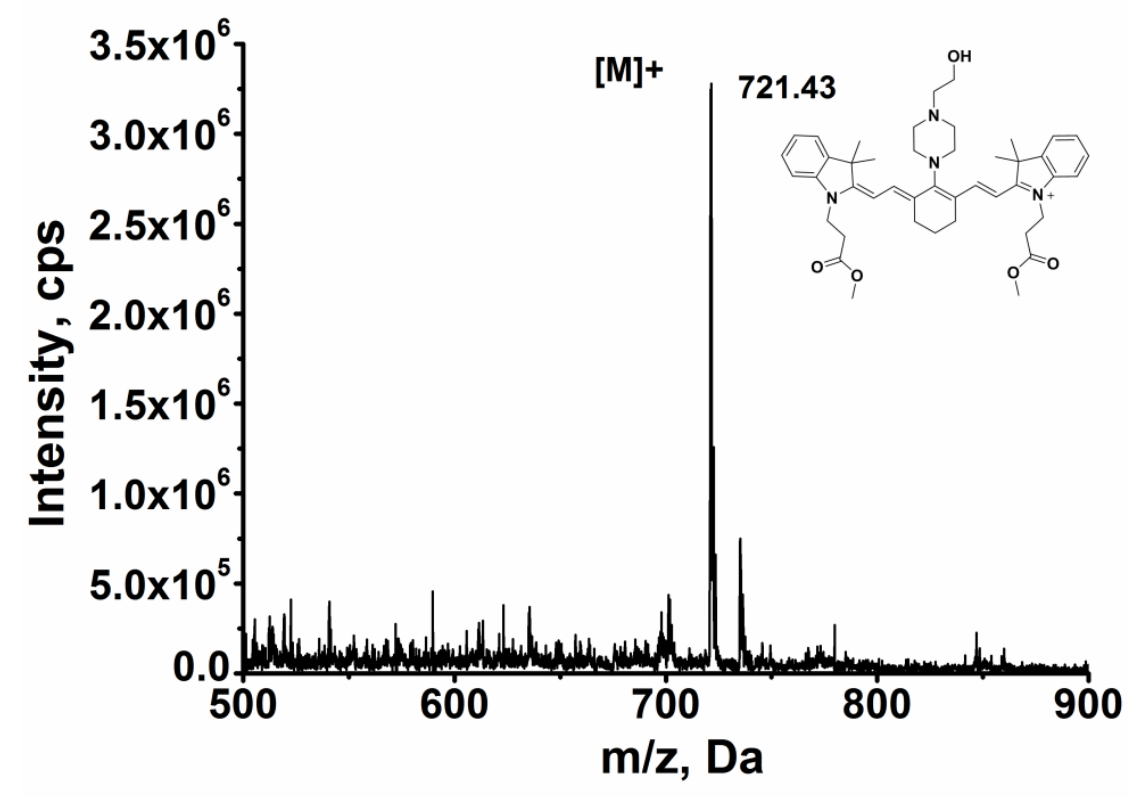

Figure S2. MS spectrum of compound 2. 


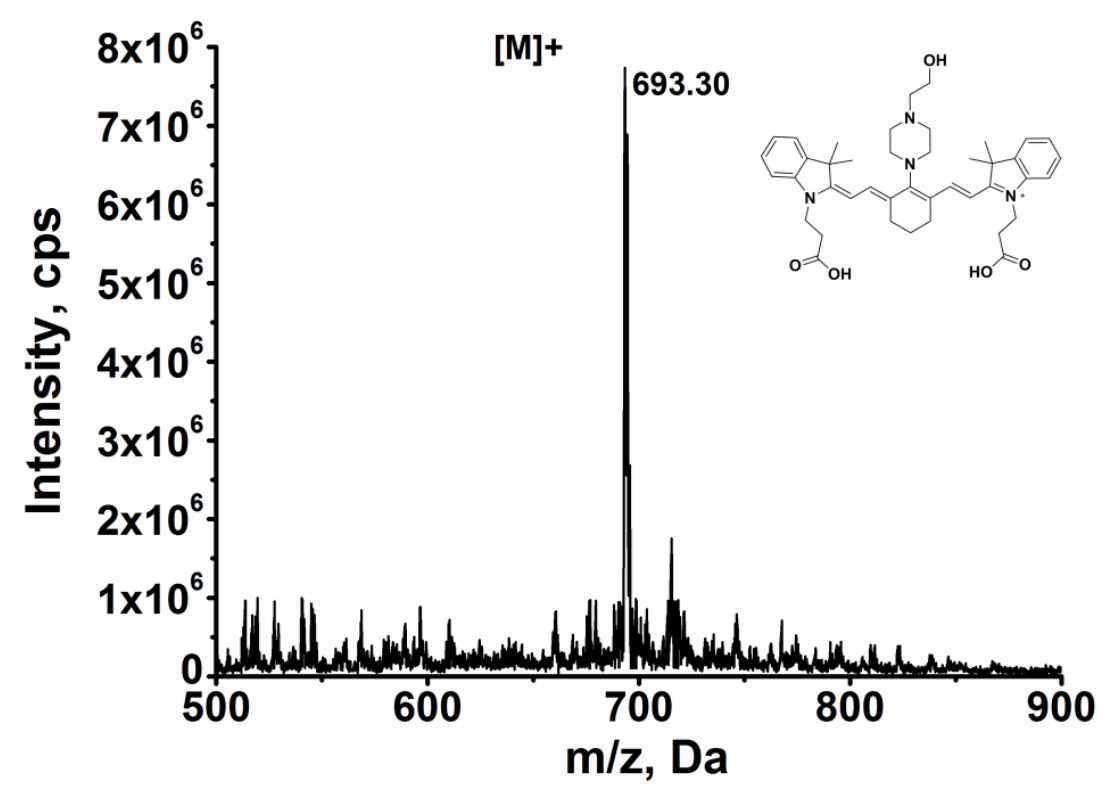

Figure S3. MS spectrum of probe. 


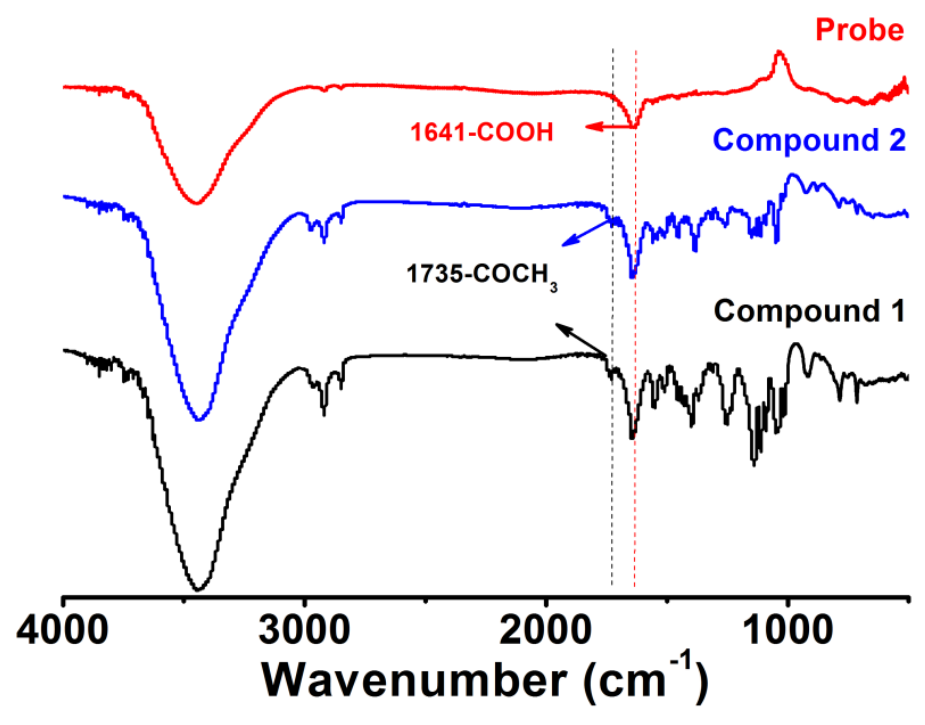

Figure S4. FT-IR spectra of probe and its intermediates. 

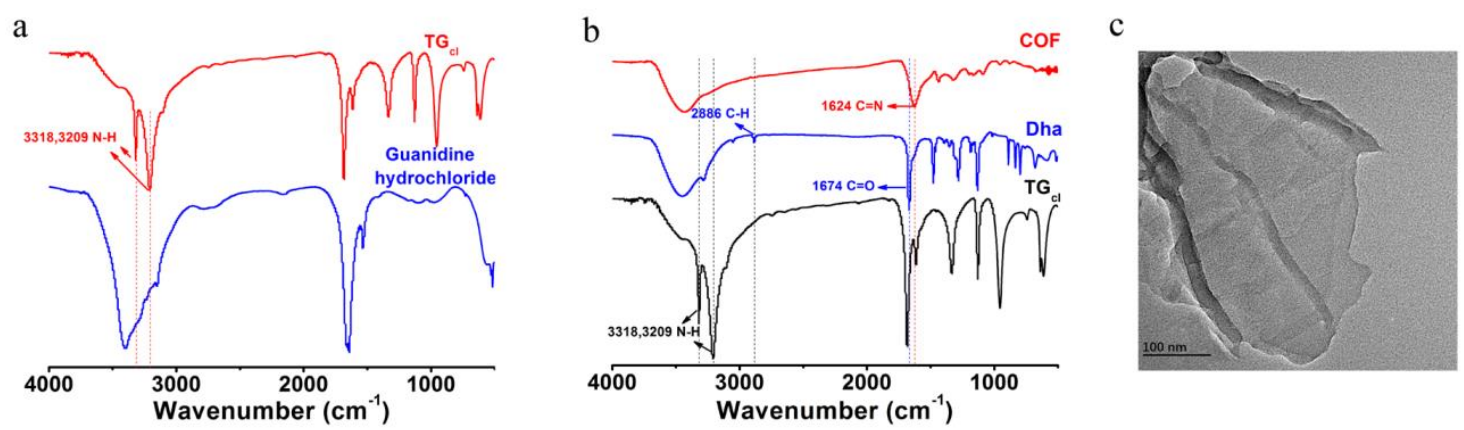

Figure S5. Characterization of COF: (a) and (b) FT-IR spectra of COF and its intermediates.

(c) TEM image of COF. 


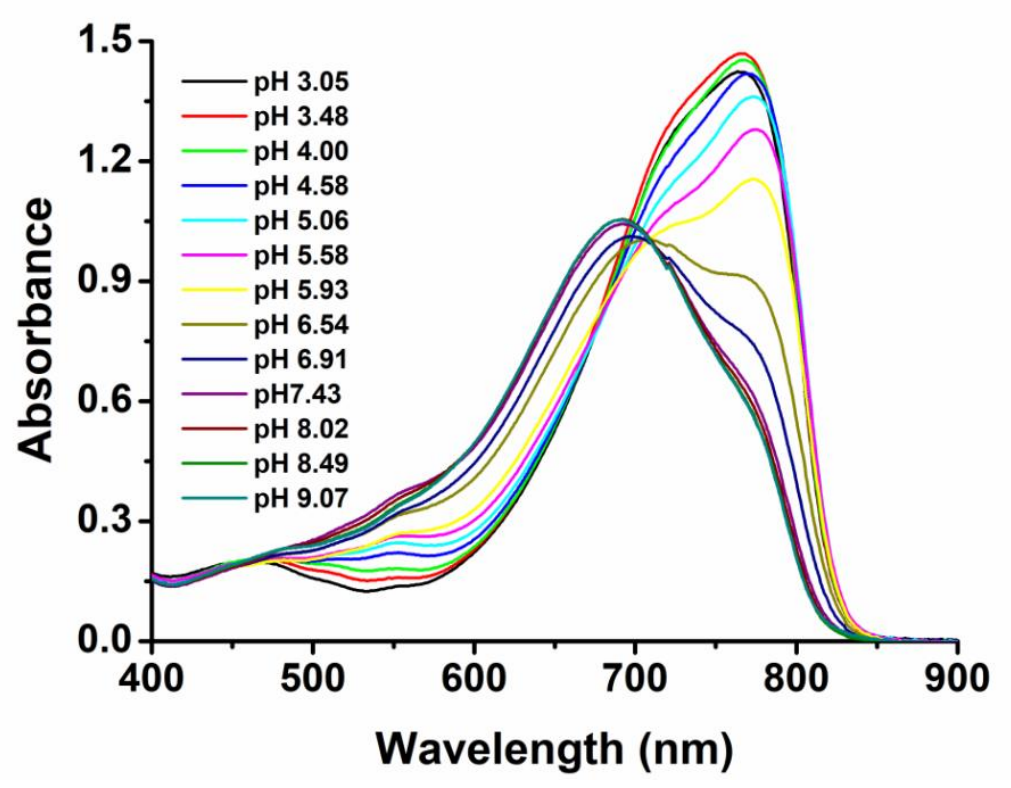

Figure S6. pH dependent UV-vis-NIR spectra of probe. 

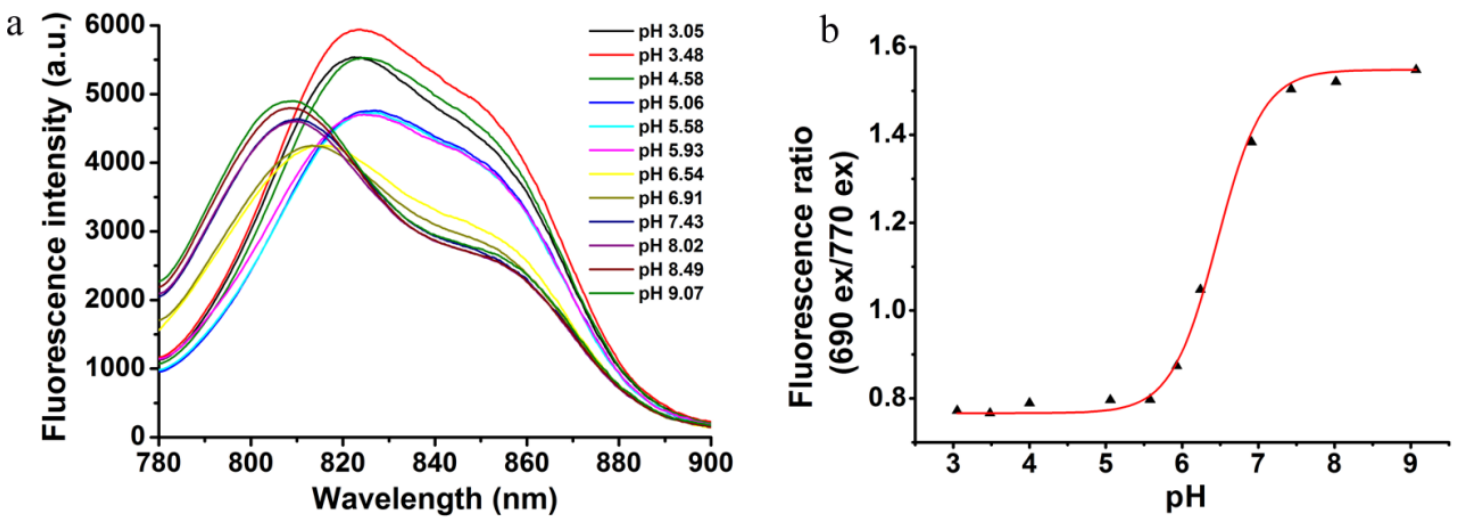

Figure S7. Fluorescence titration of probe against $\mathrm{pH}$ : (a) $\mathrm{pH}$ dependent fluorescence spectra of probe. (b) Changes in fluorescence ratio of probe $(690 \mathrm{~nm}$ excitation/770 nm excitation) at the same $\mathrm{pH}$ value. 

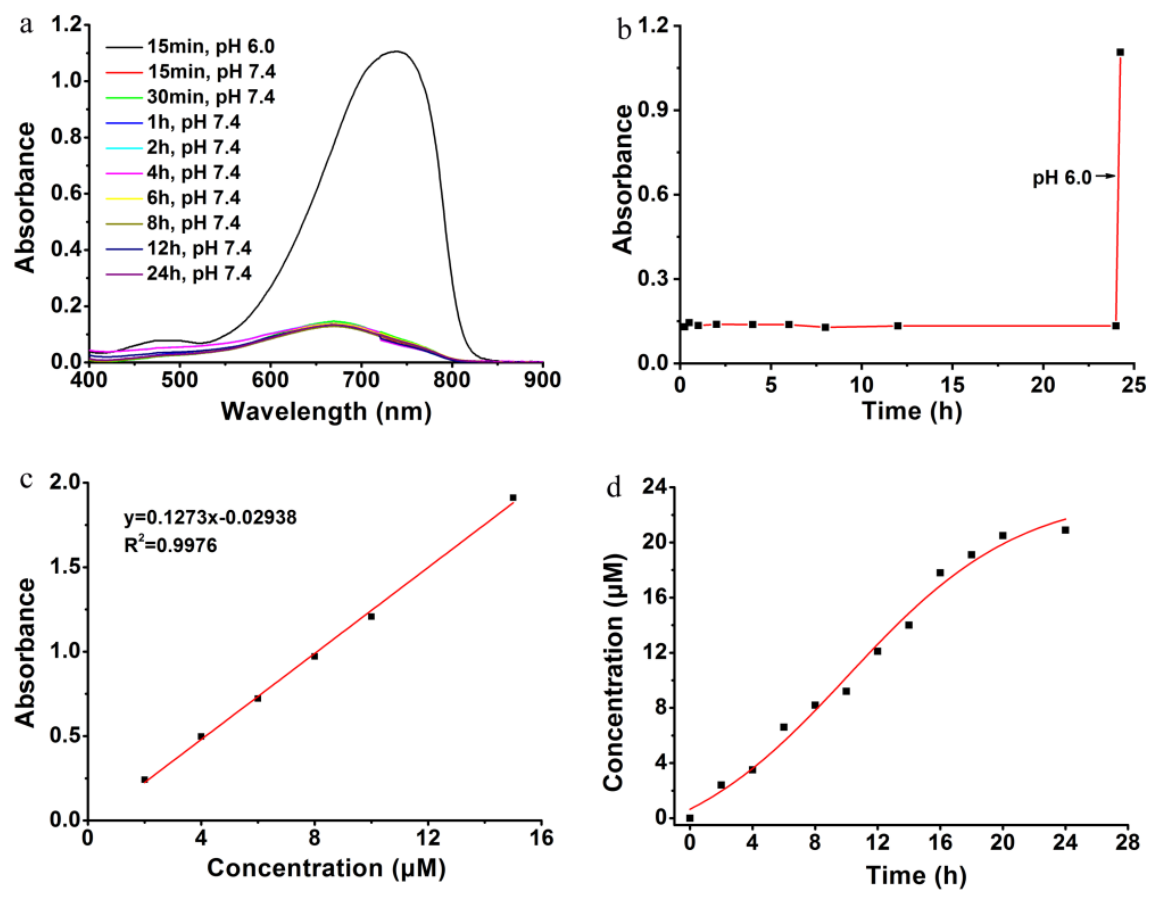

Figure S8. (a) Time-dependent absorbance of probe from COF@ probe at pH 7.4 and 6.0.

(b) Time-dependent release behavior of probe from COF@ probe at pH 7.4 and 6.0. (c)

Concentration-dependent absorbance of probe at $\mathrm{pH}$ 6.0. (d) Time-dependent adsorption curves of probe from COF@ probe. 

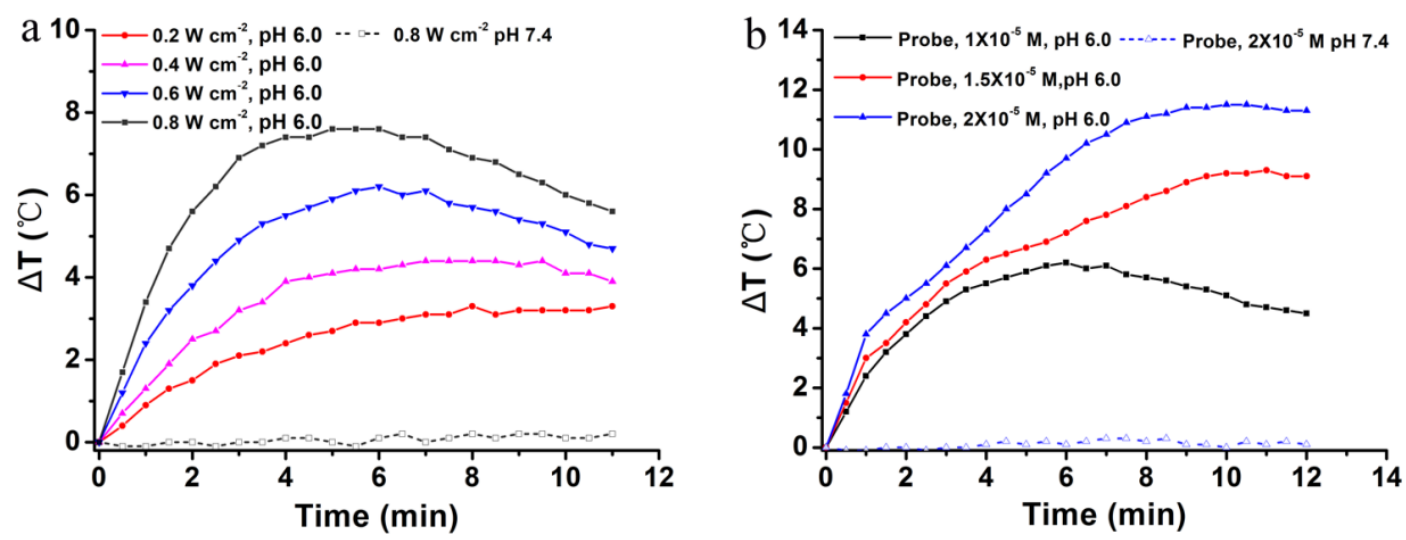

Figure S9. Photothermal property of the probe under $808 \mathrm{~nm}$ laser irradiation: (a) Irradiation time dependent temperature change curves of probe under different power of $808 \mathrm{~nm}$ laser irradiation. (b) Irradiation time dependent temperature change curves of different concentrations of probe under $0.6 \mathrm{~W} \mathrm{~cm}^{-2}$ of $808 \mathrm{~nm}$ laser irradiation. 


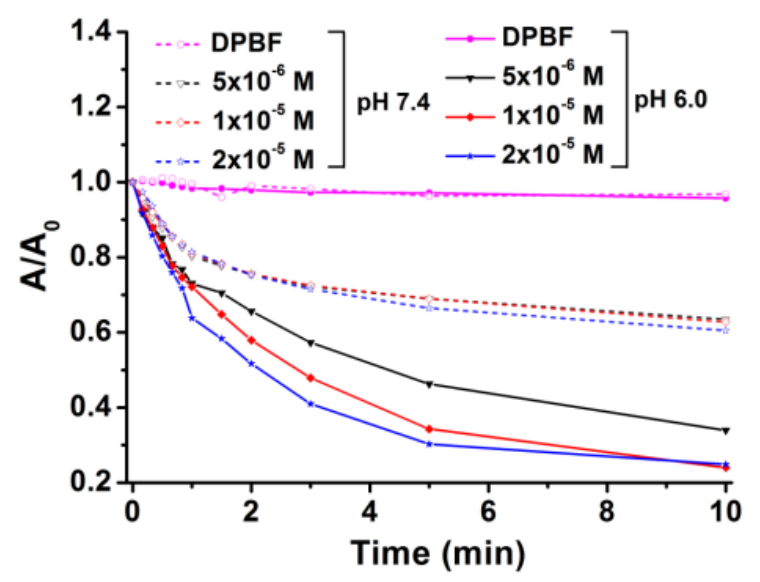

Figure S10. Time-dependent absorbance of $\operatorname{DPBF}(A / A 0)$ at $417 \mathrm{~nm}$ with or without different concentrations of probe at $\mathrm{pH} 6.0$ and 7.4 under $808 \mathrm{~nm}$ laser irradiation $(0.6 \mathrm{~W}$ $\mathrm{cm}^{-2}$ ). $A$ and $A_{0}$ are the absorbance of DPBF at a certain irradiation time and before irradiation, respectively. 



Figure S11. (a) Dark toxicity of different concentrations of probe against $S$. aureus and $E$. coli. (b) Dark toxicity of different concentrations of COF against S. aureus and E. coli. 

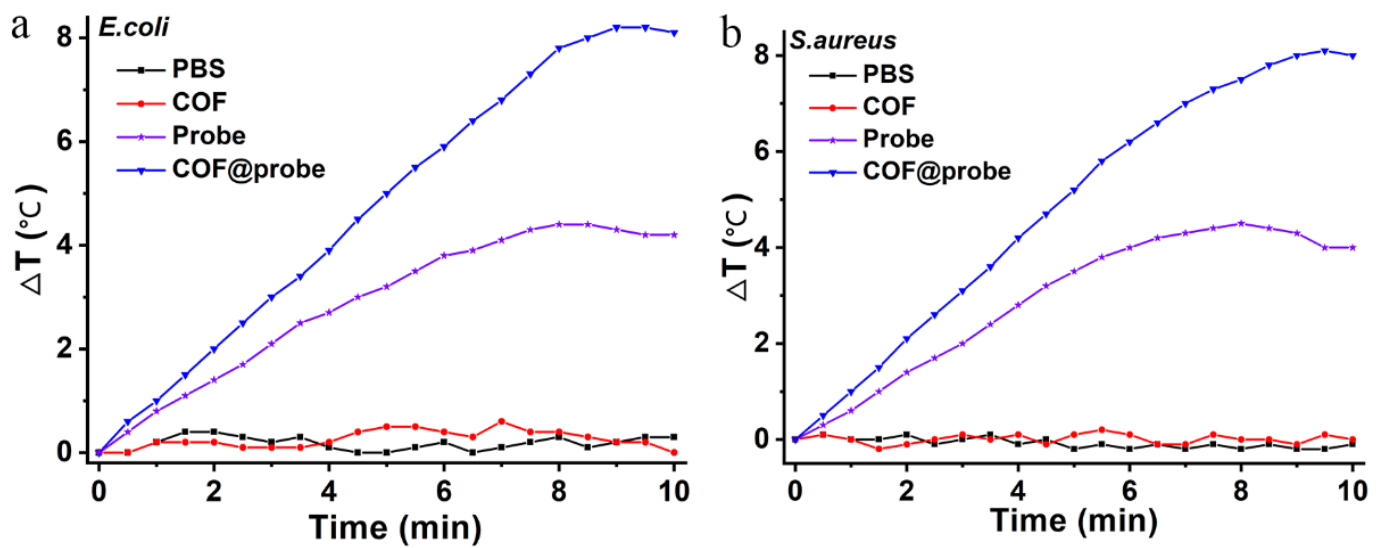

Figure S12. (a) and (b) Photothermal effect of probe, COF and COF@ probe co-incubated with $E$. coli or $S$. aureus under irradiation with an $808 \mathrm{~nm}$ laser $\left(0.6 \mathrm{~W} \mathrm{~cm}^{-2}, 10 \mathrm{~min}\right)$ 




Figure S13. Cell viability of $3 \mathrm{~T} 3$ cells incubated with probe, COF or COF@ probe $(0.5 \mathrm{mg}$ $\mathrm{mL}^{-1}, 2 \times 10^{-5} \mathrm{~mol} \mathrm{~L}{ }^{-1}$ as probe). 


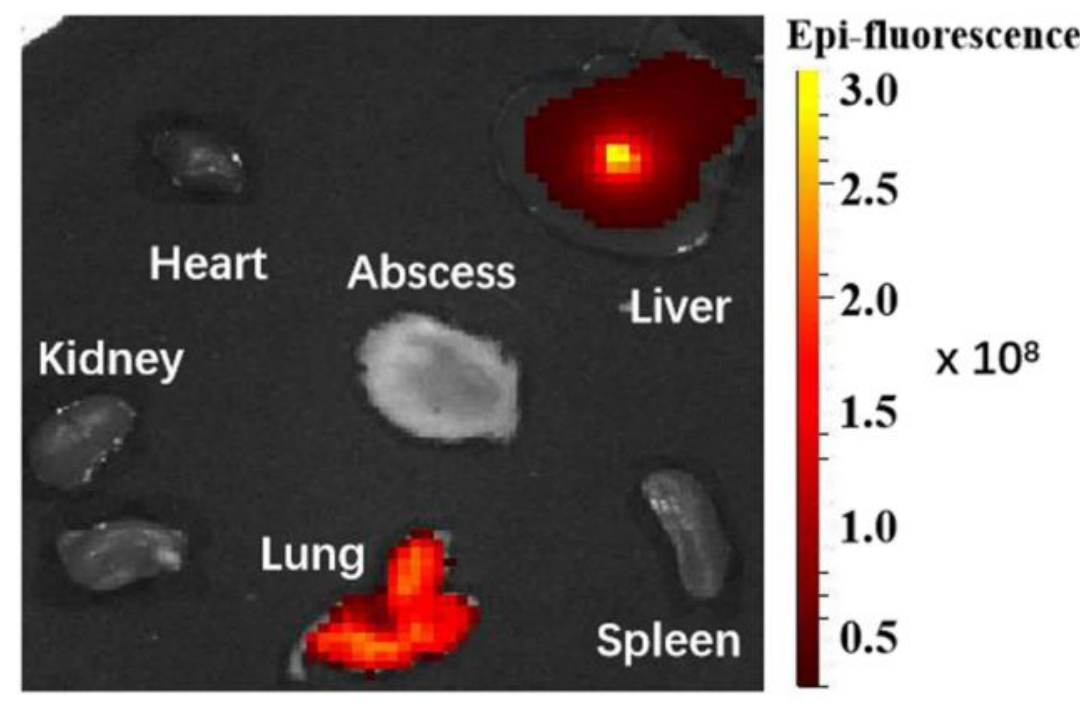

Figure S14. Ex vivo fluorescence imaging of main organs and abscesses dissected from the mice after injection with probe for $6 \mathrm{~h}$. 

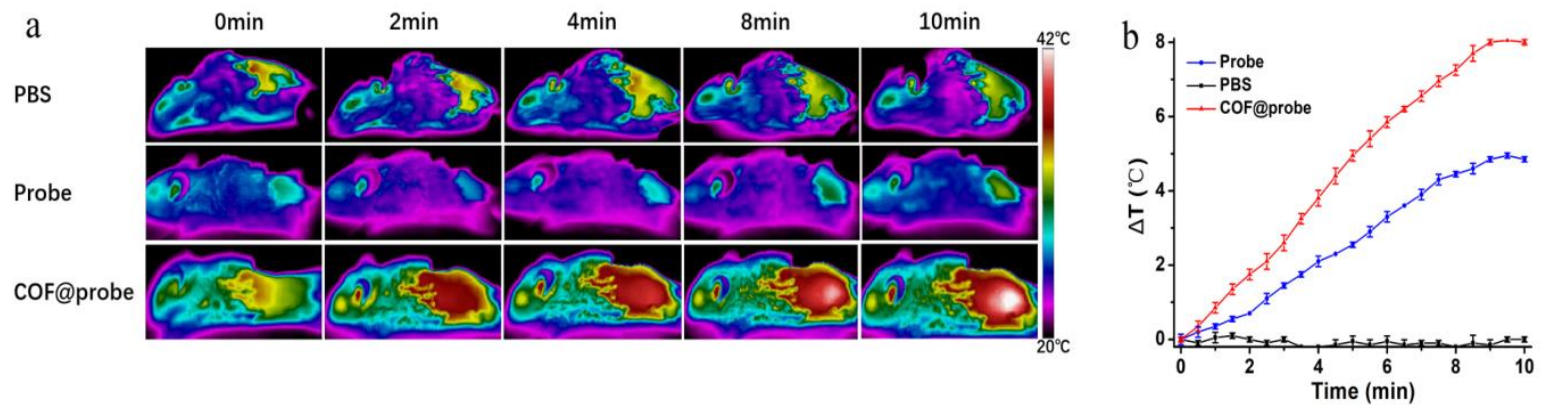

Figure S15. (a) Thermal images of abscess in mice exposed to $808 \mathrm{~nm}$ laser $\left(0.6 \mathrm{~W} \mathrm{~cm}^{-2}\right.$, $10 \mathrm{~min}$ ) for different times after $6 \mathrm{~h}$ injection of PBS, probe and COF@ probe. (b) Temperature changes of abscess in mice exposed to an $808 \mathrm{~nm}$ laser $\left(0.6 \mathrm{~W} \mathrm{~cm}^{-2}\right)$ for different times after $6 \mathrm{~h}$ post-injection of PBS, probe and COF@ probe, respectively. 


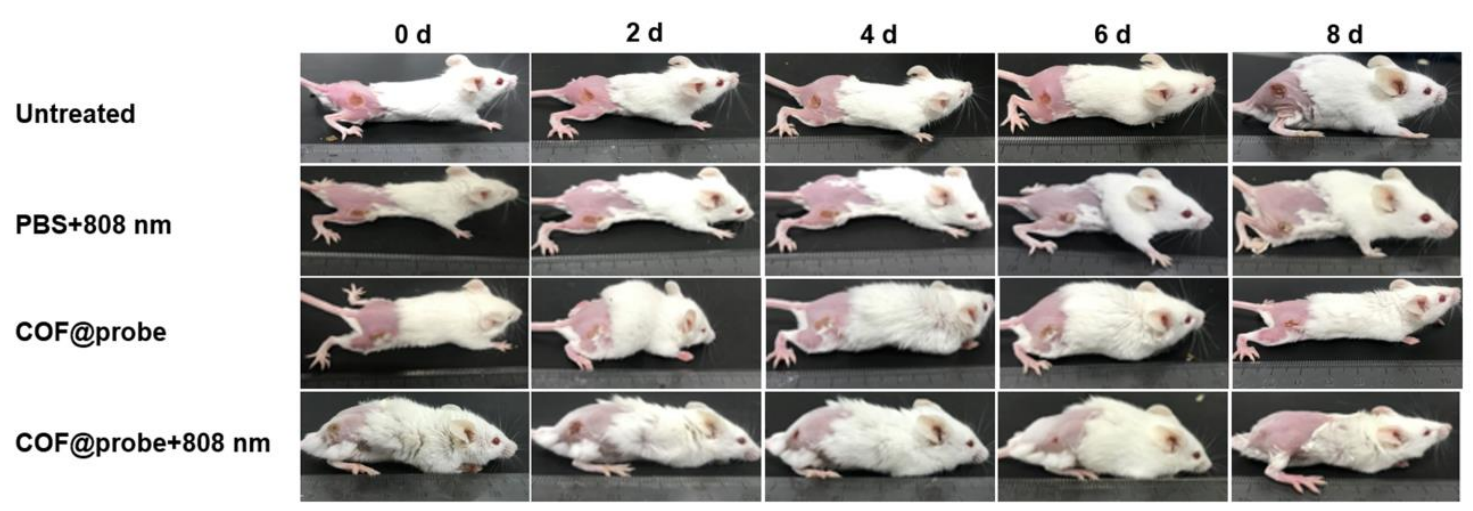

Figure S16. Representative photographs of the mice after treated with different ways for 8 days. 


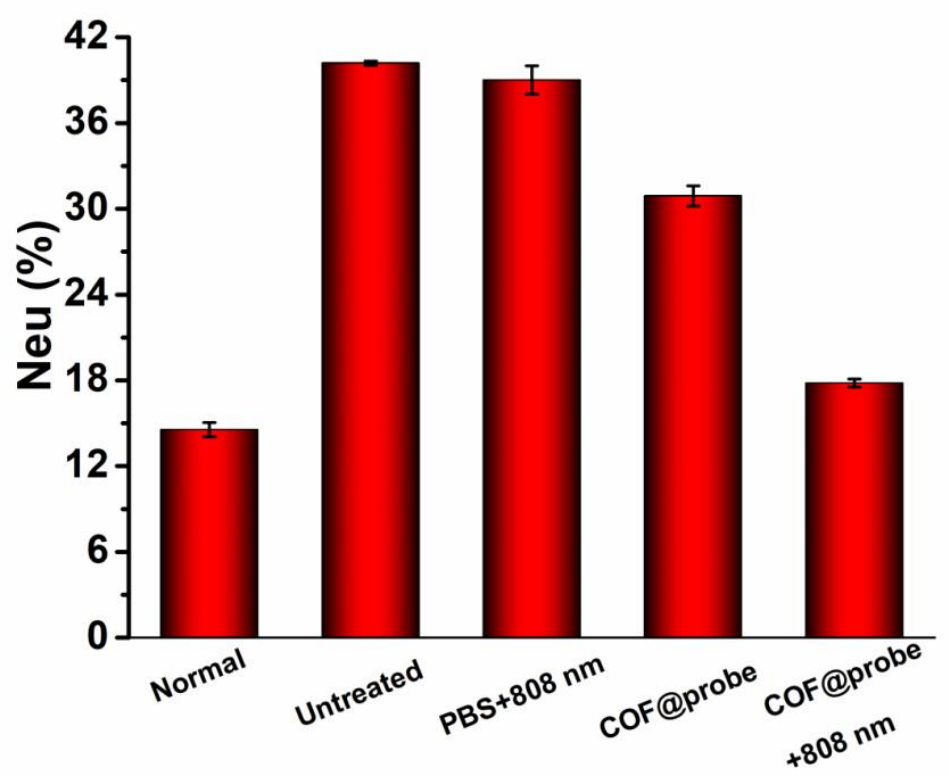

Figure S17. Neutrophil percentage in the serum of mice after 8 days treatments. 


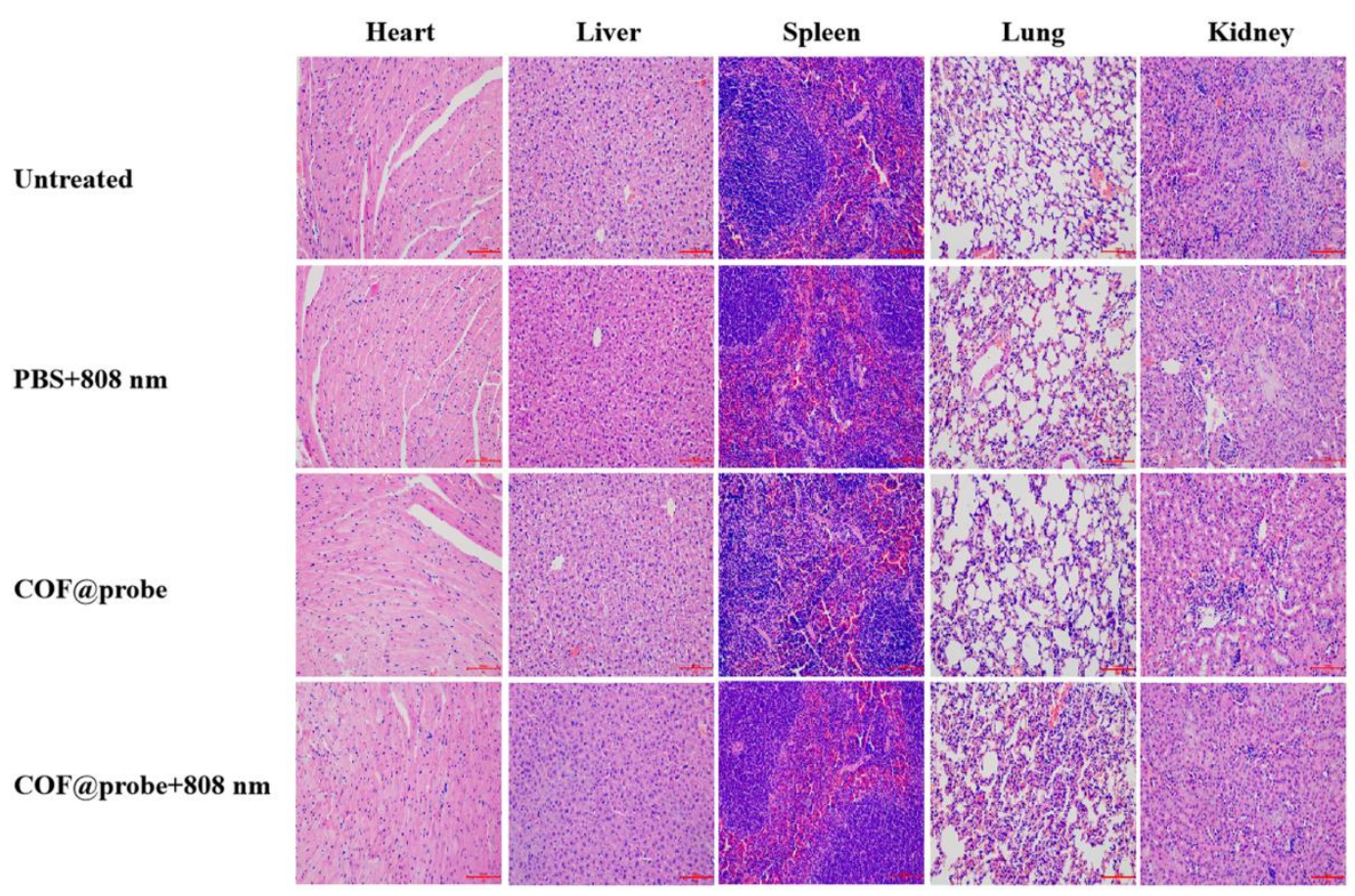

Figure S18. H\&E staining of main organs of mice after various treatments for 8 days. 